\title{
LOW BODY CONDITION SCORING AS A DETRIMENTAL FACTOR TO REPRODUCTIVE PERFORMANCE AND BEHAVIOR IN DAIRY CATTLE AND SEIDI BUFFALOES
}

\author{
MOTAMED ELSAYED MAHMOUD* ${ }^{*}$ and DOAA SALMAN** \\ *Dept. of Animal Behavior and Management, Faculty of Veterinary Medicine, Sohag University, Sohag, Egypt. \\ *** Dept. of Animal Medicine, Faculty of Veterinary Medicine, Sohag University, Sohag, Egypt.
}

\section{ABSTRACT}

Received at: 31/3/2015

Accepted: 20/4/2015
Background: Body condition scoring (BCS) is an important part of modern dairy management. BCS is an indicator of the energy reserve of dairy cattle. In dairy cattle (Bos Taurus) and buffaloes (Bos indicus) BCS indicates the amount of fat cover on skeletal parts and is directly related to reproductive performance. The aims of study: To estimate the effect of BCS on reproductive performance in cross- bred cattle and Seidi buffaloes; in trial to clarify the role of acuteness of tail angle associated with low BCS. Methods: Cross- bred cattle (50) and Seidi buffaloes (50) from 19 small scale dairy herds were examined from March to May for BCS. Morphological measures were assessed by sights and touch to evaluate each animal scale. This scale is ranging from 1 to 5 with 0.5 increments and being 1: very poor, 2: poor, 3 : moderate, 4: good, and 5: very good. Photos to side and rear views were taken, skeletal parts (pelvic bone, tail head and short ribs) were manually examined. While morphometrical measures of eight check points plus the tail angle were measured. Main Results: Animals with body condition scoring 2 or less had more acute angle of the tail and had higher \% of postpartum urovagina and anestrus when compared with that of high body condition scores. Conclusion: Low BCS and associated acute angle of the tail (horizontal position of the vulva) lead to soiled vulva, urovagina and endometritis, and consequent reduced reproductive performance in dairy cows and buffaloes.

Keywords: BCS, dairy cattle, Seidi buffaloes, tail angle, urovagina.

\section{INTRODUCTION}

Body condition score (BCS) system is a subjective method to assess the body fat reserves of farm animals, particularly over the bony prominences such as back bones and pelvic region. It gives an immediate assessment of the body state of the animal and is readily incorporated into operational decision making. This BSC system is a universally accepted, non-invasive, quick and inexpensive method to estimate the degree of fatness (Drame et al., 1999, Bittante et al., 2004). It helps evaluate the status of dairy herds nutrition program, identify lactating cows' problems, predict the cow's performance, and aid in improving the management of body fat reserves for better health, productive performance of dairy cows (Buckley et al., 2003, Bittante et al., 2004) and buffaloes (Campanile et al., 1991, Baruselli et al., 2001). Reproductive function in dairy cattle and buffaloes during the post-partum period is influenced by a number of factors that include body condition and dietary status. The importance of an optimal body condition has been demonstrated by reduced fertility in cattle that were extremely fat or thin (Campanile et al., 2006)

The aim in the present study was to identify reason for the failure of reproductive cycle and behavior in Seidi Buffaloes and cross bred cattle recorded during winter season. To our knowledge, the current study was the first to investigate acute angle of tail as risk factors for development of reproductive failure in Seidi Buffaloes and cross-bred cows.

\section{MATERIALS and METHODS}

Animals and management:

Animals included from 19-small scale producers in different localities of Sohag governorate, middle region of Egypt, under subtropical conditions. Cows were multiparous, Seidi Buffalo $(n=50)$ at $4-10$ 
years age old and $5 \pm 2$ (mean \pm SD) months of lactation. In all herds, no estrus/ovulation synchronization programs were used. Average milk production record ranged from 4 to $12 \mathrm{~kg} /$ day in cross bred cattle $(n=50)$ at $4-10$ years age old and $4.5 \pm 2$ (mean \pm SD) months of lactation. Average milk production of Seidi buffaloes ranged from 6 to 15 $\mathrm{kg} /$ day. All animal were fed on berseen and bran only. To mask or override any potential relationships with nutrition this study was conducted at a time of increasing day length which tends to suppress fertility in female buffaloes and cattle regardless of nutrition (Campanile et al., 2006). Animals with parity less than 2 and above 7 were excluded from the study. Cows were observed for signs of estrus in the morning, at noon, and in the late afternoon. Pregnancy was diagnosed by transrectal palpation, usually 40 day after insemination.

Clinical Examination: History of cases was taken from records of farms. Signs of estrous, estrous regularity, conception, repeat breeding, abortion and parity were recorded. Ageing of animals, breed, lactation stage and milk yield were also recorded.

Preparation of BCS chart:

Manual and visual examination was used to identify the 5 body condition scores according to previous studies (Edmonson et al., 1989, Rao et al., 2002, Anitha et al., 2005) as shown in Table 1.

Table 1: Indicates 4 check points examined manually to distinguish among 5 body conditions scores in Seidi Buffaloe and cross bred cattle.

\begin{tabular}{cccccc}
\hline Item & Very poor (BCS1) & Poor (BCS2) & Moderate (BCS3) & Good (BCS4) & $\begin{array}{c}\text { Very good } \\
\text { (BCS4) }\end{array}$ \\
\hline Tail head & Deep cavity & Shallow cavity & No cavity & Fold of fat & Thick fat layer \\
\hline $\begin{array}{c}\text { Pelvic } \\
\text { bone }\end{array}$ & $\begin{array}{c}\text { Sharp and easily } \\
\text { felt }\end{array}$ & $\begin{array}{c}\text { Rounded and } \\
\text { felt with press }\end{array}$ & $\begin{array}{c}\text { Felt with slight } \\
\text { press }\end{array}$ & $\begin{array}{c}\text { Felt with firm } \\
\text { press }\end{array}$ & Not felt \\
\hline $\begin{array}{c}\text { Short ribs } \\
\text { Loin area }\end{array}$ & $\begin{array}{c}\text { Sharp and easily } \\
\text { felt }\end{array}$ & $\begin{array}{c}\text { Felt with slight } \\
\text { press }\end{array}$ & Felt with firm press & Not felt & Not felt \\
\hline Deepression & $\begin{array}{c}\text { Visible } \\
\text { depression }\end{array}$ & Slight depression & No depression & No depression \\
\hline
\end{tabular}

\section{Statistical analysis}

Statistical analysis of data was performed by Graph Pad prism software. One-way ANOVA was used for multiple comparisons and T-test was used to compare the reproductive performance between the highest and lowest body condition scores. The values were found to be significant only at 0.05 level.

\section{RESULTS}

Signs of estrous behavior:

The common signs of estrous behavior observed by animal's owners and attendants to detect heat were divided into; 1) general behavioral signs associated with heat which included; restlessness, excitement, decrease feed intake, decreased rumination, decreased milk yield and 2) specific behavioral signs of heat which included; vocalization, estrous mucous, standing to be mounted, mounting other animals, steaming of flank region by claws of others (dirty flank), swollen and red vulva, and licking other animals. In both cattle and buffaloes, there were remarkable differences for timing of first estrous after calving and calving intervals. There was tendency for delayed first postpartum estrous and estrus interval and calving interval when BCS was below 2 (Table 2A \& B)

\section{Reproductive parameters}

Table 2 A: Reproductive parameters in Seidi Bufaloes.

\begin{tabular}{ccccccc}
\hline & Item & $\geq$ BCS1 & $\leq$ BCS2 & $\leq$ BCS3 & $\leq$ BCS4 & $\leq$ BCS5 \\
\hline 1 & Parity & $2-7$ & $2-6$ & $2-5$ & $2-7$ & $2-5$ \\
\hline 2 & First post partum estrous & $\geq 140$ days & $\leq 70$ days & $\leq 50$ days & $\leq 40$ days & $\leq 40$ days \\
\hline 3 & Regularity of estrous interval & $7.4 \%$ & $24.8 \%$ & $71.8 \%$ & $82 \pm 12 \%$ & $88 \pm 6.0 \%$ \\
\hline 4 & Repeat breeding & $76.9 \%$ & $34.12 \%$ & $24.6 \%$ & $7.0 \pm 2.0 \%$ & $4.0 \pm 0.5 \%$ \\
\hline 5 & Previous abortion & $1.64 \%$ & $1.12 \%$ & $2.1 \%$ & $0.0 \%$ & $0.0 \%$ \\
\hline
\end{tabular}


$\underline{\text { Assiut Vet. Med. J. Vol. } 61 \text { No. } 145 \text { April } 2015}$

Table 2 B: Reproductive parameters in cross bred cattle.

\begin{tabular}{ccccccc}
\hline & Item & $\geq$ BCS1 & $\leq$ BCS2 & $\leq$ BCS3 & $\leq$ BCS4 & $\leq$ BCS5 \\
\hline 1 & Parity & $2-7$ & $2-6$ & $2-5$ & $2-7$ & $2-5$ \\
\hline 2 & First post partum estrous & $\geq 90$ & $\leq 60$ days & $\leq 50$ days & $\leq 40$ days & $\leq 40$ days \\
\hline 3 & Regularity of estrous interval & $7.4 \%$ & $24.8 \%$ & $71.12 \%$ & $79 \pm 12 \%$ & $92 \pm 6.0 \%$ \\
\hline 4 & Repeat breeding & $87.11 \%$ & $82.12 \%$ & $25 . \pm 9.0 \%$ & $14.8 \pm 2.0 \%$ & $7.0 \pm 0.4 \%$ \\
\hline 5 & Previous abortion & $2.69 \%$ & $1.45 \%$ & $1.0 \%$ & $0.0 \%$ & $0.0 \%$ \\
\hline
\end{tabular}

Data presented in Tables $2 \mathrm{~A}$ and B showed that cows and buffaloes under body condition score 2 had delayed postpartum estrous exceeding 60 days.

\section{Morphometrical assessment of BCS}

Anatomical differences reported between buffaloe and cattle skeletons. e.g. the spinous processes of lumbar vertebrae were narrow and pointed at the ends in buffalo, while it is wide and blunt at the ends in cattle. The tips of lumbar transverse processes were narrow and pointed in buffalo and broad in cattle while the ribs were more curved in the buffalo and less in cattle (Malik et al., 1990 and 1992, Anitha et al., 2010). The pelvic measurements between sacral tubers, between hooks and sacral tubers, distance between pins and the height of pelvic outlet were greater in Seidi buffaloes compared to cross bred cattle, whereas the length of dorsal sacral crest and between hooks and pins distance were less in buffalo when compared to that of cattle (Table $3 \mathrm{~A} \& \mathrm{~B}$ ).

Identification of the BCS check points:

Eight skeletal checkpoints were examined by using BCS chart (Anitha et al., 2010) in addition to tail angle measurement. The tail angle between vulva and origin of the tail, while the tail was being stretched, was measured using an ordinary protractor on an electric wire previously adopted to be bend under the tail. The eight locations measured as shown in Table 3 A and B. After each check point was measured by girth meter, the scores were recorded and the average BCS was assigned to the same herd of 50 buffaloes and 50 cattle.

Table 3 A: Morphometrical measures of 9 check points in 5 body condition scores in Seidi buffaloes.

\begin{tabular}{|c|c|c|c|c|c|}
\hline Point & $\geq$ BCS1 & $\leq \mathrm{BCS2}$ & $\leq \mathrm{BCS3}$ & $\leq \mathrm{BCS4}$ & $\leq \mathrm{BCS5}$ \\
\hline $\begin{array}{l}\text { 1- Length of concave depression } \\
\text { between dock and pins }\end{array}$ & $44.5 \pm 0.9^{\mathrm{a}}$ & $40.5 \pm 2.1^{\mathrm{b}}$ & $34.0 \pm 1.9^{c}$ & $29.5 \pm 0.8^{d}$ & $29.5 \pm 0.9^{\mathrm{d}}$ \\
\hline $\begin{array}{l}\text { 2- Inverted "V" shaped projection - for } \\
\text { spinous processes of the lumbar } \\
\text { vertebrae }\end{array}$ & $15.5 \pm 0.7^{\mathrm{a}}$ & $10.5 \pm 0.7^{b}$ & $8.5 \pm 0.7^{c}$ & $6.5 \pm 0.7^{c}$ & $6.5 \pm 0.7^{\mathrm{c}}$ \\
\hline 3- "V" shaped cavity under the tail & $20.5 \pm 0.8^{a}$ & $16.0 \pm 1.4^{b}$ & $11.0 \pm 1.4^{\mathrm{c}}$ & $8.3 \pm 0.3^{\mathrm{d}}$ & $8.3 \pm 0.4^{\mathrm{d}}$ \\
\hline $\begin{array}{l}\text { 4- "L"-shaped depression between } \\
\text { spinous and transverse process of the } \\
\text { lumbar vertebrae }\end{array}$ & $19.5 \pm 0.7^{\mathrm{a}}$ & $15.5 \pm 0.7^{b}$ & $12.0 \pm 1.2^{\mathrm{c}}$ & $10.5 \pm 0.7^{c}$ & $10.5 \pm 0.7^{\mathrm{c}}$ \\
\hline $\begin{array}{l}5-">" \text { shaped transverse processes of } \\
\text { lumbar vertebrae }\end{array}$ & $7.5 \pm 0.5^{\mathrm{a}}$ & $4.8 \pm 0.4^{b}$ & $3.3 \pm 0.4^{\mathrm{b}}$ & $2.8 \pm 0.6^{\mathrm{b}}$ & $2.8 \pm 0.4^{\mathrm{b}}$ \\
\hline $\begin{array}{l}\text { 6- " (" shaped depression between 12th } \\
\text { and 13th ribs }\end{array}$ & $19.5 \pm 0.6^{\mathrm{a}}$ & $18.5 \pm 0.7^{\mathrm{a}}$ & $14.0 \pm 1.1^{\mathrm{b}}$ & $11.5 \pm 0.7^{b}$ & $11.5 \pm 0.7^{b}$ \\
\hline $\begin{array}{l}\text { 7- A concave depression between hooks } \\
\text { and pins. }\end{array}$ & $44.8 \pm 0.4^{\mathrm{a}}$ & $41.5 \pm 0.6^{\mathrm{a}}$ & $37.0 \pm 1.5^{b}$ & $34.5 \pm 0 .^{b}$ & $34.5 \pm 0.9^{b}$ \\
\hline $\begin{array}{l}\text { 8- A concave depression between sacral } \\
\text { crest and hooks }\end{array}$ & $48.5 \pm 0.7^{\mathrm{a}}$ & $44.0 \pm 1.4^{b}$ & $30.5 \pm 0.7^{\mathrm{c}}$ & $28.5 \pm 1.2^{\mathrm{c}}$ & $28.5 \pm 0.7^{\mathrm{c}}$ \\
\hline $\begin{array}{l}\text { 9- Tail angle }\left({ }^{\circ}\right) \text { between vulva and } \\
\text { dock }\end{array}$ & $40-50$ & $50-55$ & $55-65$ & $65-80$ & $80-90$ \\
\hline
\end{tabular}


Assiut Vet. Med. J. Vol. 61 No. 145 April 2015

Table 3 B: Morphometrical measures of 9 check points in 5 body condition scores in cross bred cattle.

\begin{tabular}{|c|c|c|c|c|c|}
\hline Point & $\geq$ BCS1 & $\leq \mathrm{BCS2}$ & $\leq \mathrm{BCS3}$ & $\leq \mathrm{BCS} 4$ & $\leq \mathrm{BCS5}$ \\
\hline $\begin{array}{l}\text { 1- Length of concave depression } \\
\text { between dock and pins }\end{array}$ & $40.5 \pm 0.7$ & $37.3 \pm 0.4$ & $33.0 \pm 2.1$ & $25 \pm 0.8$ & $22.0 \pm 0.6$ \\
\hline $\begin{array}{l}\text { 2- Inverted " V" shaped projection - } \\
\text { for spinous processes of the lumbar } \\
\text { vertebrae }\end{array}$ & $9.0 \pm 0.7$ & $7.5 \pm 0.7$ & $5.5 \pm 0.5$ & $4.7 \pm 0.5$ & $4.5 \pm 0.1$ \\
\hline 3- "V" shaped cavity under the tail & $25.0 \pm 0.8$ & $23.3 \pm 1.5$ & $20.8 \pm 1.1$ & $19.0 \pm 1.0$ & $15 \pm 0.5$ \\
\hline $\begin{array}{l}\text { 4- "L"-shaped depression between } \\
\text { spinous and transverse process of the } \\
\text { lumbar vertebrae }\end{array}$ & $18.5 \pm 0.7$ & $20.0 \pm 0.4$ & $13.5 \pm 0.7$ & $11.5 \pm 0.7$ & $25 \pm 0.1$ \\
\hline $\begin{array}{l}\text { 5- " >" shaped transverse processes } \\
\text { of lumbar vertebrae }\end{array}$ & $4.5 \pm 0.4$ & $4.0 \pm 0.1$ & $3.5 \pm 0.2$ & $2.2 \pm 0.1$ & $2.1 \pm 0.2$ \\
\hline $\begin{array}{l}6-" \text { " (" shaped depression between } \\
12 \text { th and 13th ribs }\end{array}$ & $3.6 \pm 0.2$ & $3.4 \pm 0.4$ & $2.6 \pm 0.3$ & $2.5 \pm 0.1$ & $2.0 \pm 0.2$ \\
\hline $\begin{array}{l}\text { 7- A concave depression between } \\
\text { hooks and pins. }\end{array}$ & $47.5 \pm 0.13$ & $40.3 \pm 1.3$ & $37.0 \pm 1.0$ & $29.5 \pm 0.7$ & $25.0 \pm 1.3$ \\
\hline $\begin{array}{l}\text { 8- A concave depression between } \\
\text { sacral crest and hooks }\end{array}$ & $18.5 \pm 0.7$ & $17.0 \pm 1.4$ & $5.0 \pm 0.4$ & $7.0 \pm 0.3$ & $5.0 \pm 0.1$ \\
\hline $\begin{array}{l}\text { 9- Tail angle }\left({ }^{\circ}\right) \text { between vulva and } \\
\text { dock }\end{array}$ & $45-60$ & $60-70$ & $70-80$ & $80-85$ & $85-90$ \\
\hline
\end{tabular}

A

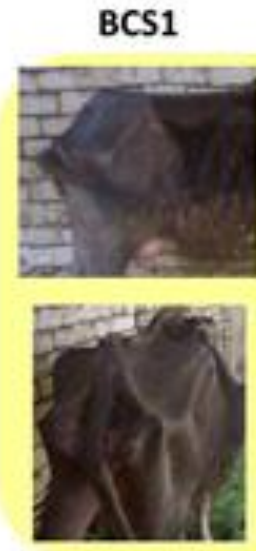

B

BCS1

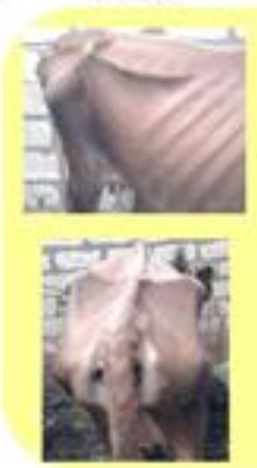

BCS2
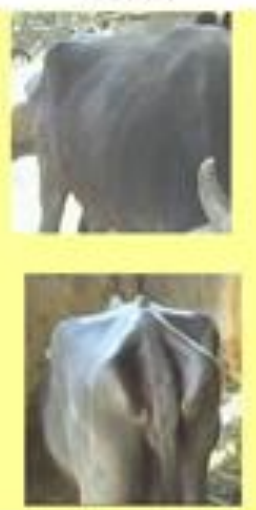

BCS2
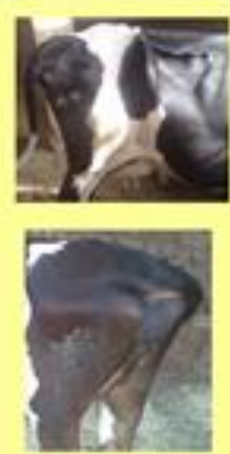

BCS3
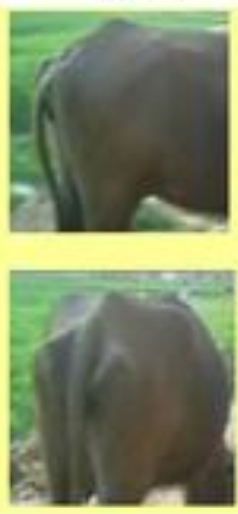

BCS3
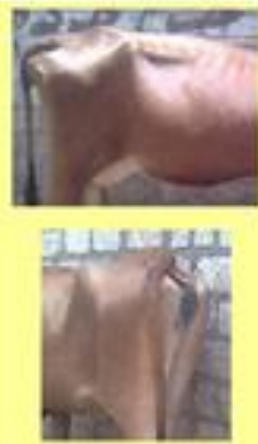

BCS4
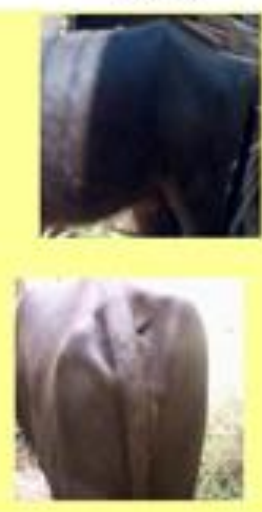

BCS4
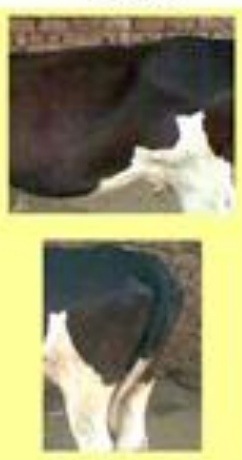

BCS5
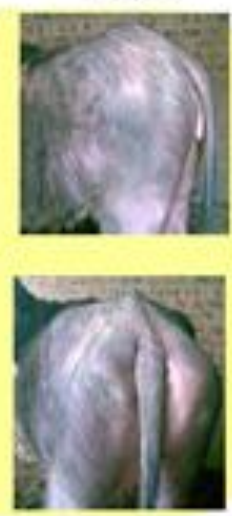

BCS5

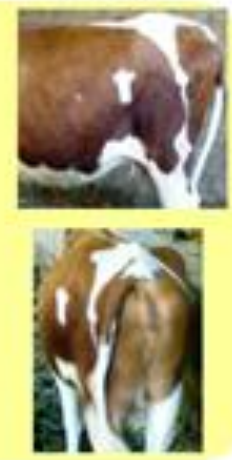

Slide 1: Body condition scoring in Seidi buffaloe (A) and cross-bred cattle (B) 


\section{DISCUSSION}

Despite the relationship between BCS and reproductive performance is well illustrated but the link between acuteness of tail angle at low BCS and reproductive failure was not clear. In this study we showed that low BCS and associated acute angle of the tail (horizontal position of the vulva) lead to soiled vulva, urovagina and endometritis, and consequent reduced reproductive performance in dairy cows and buffaloes. Cows with high genetic merit for BCS lose less body condition in early lactation, and therefore experience less negative energy balance. In addition, body condition loss became more severe, days to first service is a favorable genetic correlations between fertility (days to first service and non-return rate) and BCS. Moreover, cows that were thinner (lower body condition) had longer calving intervals (Dechow et al., 2002, Kadarmideen and Wegmann, 2003).

In both cattle and buffaloes low body condition at calving reduces reproductive performance in terms of prolonged intervals to first post partum oestrus reaching to 3 months compared to 40 days in high $\mathrm{BCS}$, plus irregular estrous and increased percentage of repeat breeding and abortion (Tables 2A \& 2B). This was in agreement with previous reports (Cutullic et al., 2011, Dubuc et al., 2012).

The ideal body reserves for pregnant, lactating and non-lactating farm animals allow them to attain maximum milk production with minimum metabolic disorders. Body weight alone is not a good indicator of body reserves. The visual and tactile assessment of animal condition provides a good measurement of body fat reserves and minimizes the influence of frame sizes and intestinal contents (Ferguson et al., 1994). As body condition is the reflections of the fat reserves carried by the animal. The ability to estimate the body condition accurately to production of the animal would help the farmers to increase the overall efficiency of feeding and management of farm animals. Keeping this in view, during the last three decades the traditional and subjective assessment of the body reserves in farm animals made by eye and touch, has been rationalized by the introduction of numerical systems of rating specific anatomical points. A BCS chart in a 1 to 5 scale using 0.25 increments was developed for Holstein dairy cows (Edmonson et al., 1989, Rao et al., 2002, Anitha et al., 2005). Various studies on the precision of BCS system, including the ultrasonic assessment of subcutaneous fat, indicated that BCS values were closely related to the actual measurement of subcutaneous fat (Lubis and Fletcher, 1985; Domecq et al., 1995; Zulu et al., 2001).
As it is well known that as the BCS increased, the amount of fat reserves also increased significantly, indicating that BCS adequately reflects the amount of actual fat reserves (Anitha et al., 2010). The difference in the fat thickness measurements might be attributed to the species differences. Body condition is scored with only the check points that decisively contributed to the differences among scores. Hence, the BCS system can be separated by 0.5 increments, in accordance with the findings of Ferguson et al. (1994) who reported that BCS can only be separated by 0.5 units for scores less than 2.5 and greater than 4.0. A new valid BCS chart on a 1 to 5 scale using 0.5 increments to examine 8 skeletal check points was adopted by Anitha et al. (2010) in Murrah buffaloes. For dairy cows, 8, 9 and 10 check point scales are used in Australia, Denmark and New Zealand (Lassen et al., 2003, Roche et al., 2004). Prevailing scoring systems for dairy cows in the United States and Ireland use a 5-point scale. The differences in the check points may be attributed to the species and breed differences in the animals.

Cattle and buffaloes with an optimal body condition at calving have a reduced calving to conception interval due to an earlier resumption of cyclic ovarian activity and fewer services per conception (Hegazy et al., 1994, Baruselli et al., 2001, Parkinson 2001, Fubini and Ducharme 2004). Energy balance is also important and buffaloes in negative energy balance showed a reduced ovarian follicular activity and a delay in post-partum ovulation (Campanile et al., 1991). Accumulation of urine in the vagina of a cow was diagnosed as urovagina and was classified into mild (urine only on the floor of vagina), moderate (urine covering less than or equal to half portion of the external cervical os), or severe (urine covering more than half or whole portion of the external cervical os) (Nakao et al., 1992, Gautam and Nakao, 2009, Gautam et al., 2010, Zobel et al., 2012). There are some reports describing the surgical correction and treatment of urovagina (Gilbert et al., 1989, Kasimanickam et al., 2004, Williams et al., 2005, Barlund et al., 2008, Zobel et al., 2012) and prevalence of urovagina, and its impact on reproductive performance (McDougall et al., 2007, Runciman et al., 2008, Gautam, and Nakao, 2009, Gautam et al., 2010). However, the effect of body condition on incidence of urovagina has not been well described in the literature. The etiology of urovagina is not known, stretching of the suspensory apparatus of the genital tract as a result of as a result of dystocia, twinning and/or successive pregnancies was reported (Gilbert et al., 1989, Parkinson 2001, Fubini and Ducharme 2004, Runciman et al., 2008). This condition is considered an important cause of subfertility in dairy cows, compromising animal health and resulting in production and economic losses (Gilbert et al., 1989; Gautam and Nakao 2009). Prevalence of urovagina and its impact on 
reproductive performance has not been well described in the literature regarding Seidi bufflaoes.

In this study we emphasized that low body condition scoring was associated with reduced tail angle and increased possibility of urovagina in cattle and buffaloes as shown in Tables ( $3 \mathrm{~A}$ and $3 \mathrm{~B}$ ). In fact there was a high incidence of repeat breeding or anestrus in low BCS. It is evident that there is a high incidence of endometritis in cows with moderate and severe degrees of urovagina compared with that in cows with no urovagina (Gautam and Nakao, 2009, Gautam et al., 2010). To conclude, the present study suggested that acuteness of tail angle was associated with reproductive failure in terms of delayed postpartum estrus and prolonged calving intervals in dairy cows and buffaloes.

\section{ACKNOWLEDGMENTS}

The authors would like to thank the graduate students, Faculty of Veterinary Medicine, Sohag University for collecting some data.

\section{REFERENCES}

Anitha, A.; Sarjan Rao, K.; Ramana, JV. and Satyanarayana Reddy, PVV. (2005): Body conditions score and its relation to age and physical parameters in crossbred cows. Indian Vet. J., 82: 305-308.

Anitha, A.; Sarjan Rao, K.; Jeepalyam1, S.; Moorthy, S.; Rangappa, P. and Reddy, PVV. (2010): Development of the body condition score system in Murrah buffaloes: validation through ultrasonic assessment of body fat reserves. J. Vet. Sci., 11: 1-8.

Barlund, CS.; Carruthers, TD.; Waldner, CL. and Palmer, CW. (2008): A comparison of diagnostic techniques for postpartum endometritis in dairy cattle. Theriogenology, 69: 714-23.

Baruselli, PS.; Barnabe, VH.; Barnabe, RC.; Visintin, JA.; Molero-Filho, JR. and Porto Filho, R. (2001): Effect of body condition score at calving on postpartum reproductive performances in buffalo. Buff J, 1: 53-65.

Bittante, G.; Gallo, L.; Carnier, P.; Comin, A. and Cassandro, M. (2004): Management and breeding of cows using body condition score. Informatore Agrario, 60: 55-58.

Buckley, F.; Sullivan, KO.; Mee, JF.; Evans, RD. and Dillon, P. (2003): Relationships among milk yield, body condition, cow weight and reproduction in spring calved Holstein Fresians. J. Dairy Sci., 86: 2308-2319.

Campanile, G.; Di Palo, R.; Esposito, L.; Boni, R. and Zicarelli, L. (1991): Influenza dei fabbisogni produttivie del clima su alcune caratteristiche dell'estro nella bufala. In: Proc IX Congr Naz ASPA, p 180-200.

Campanile, G.; Neglia, G.; Di Palo, R.; Gasparrini, B.; Bacelli, C.; D'Occhio, M.J. and Zicarelli, L. (2006): Relationship of body condition score and blood urea and ammonia to pregnancy in Italian Mediterranean buffaloes. Reprod Nutr Dev., 46: 57-62.

Cutullic, E.; Delaby, L.; Gallard, Y. and Disenhaus, C. (2011): Dairy cows' reproductive response to feeding level differs according to the reproductive stage and the breed. Animal 5: 731-40.

Dechow, C.D.; Rogers, G.W. and Clay, J.S. (2002): Heritability and correlations among body condition score loss, body condition score, production and reproductive performance. J. Dairy Sci., 85: 3062-3070.

Domecq, JJ.; Skidmore, AL.; Lloyd, JW. and Kaneene, JB. (1995): Validation of body condition scores with ultrasound measurements of subcutaneous fat of dairy cows. J. Dairy Sci., 78: 2308-2313.

Drame, ED.; Hanzen, CH.; Houtain, JY.; Laurent, Y. and Fall, A. (1999): Evolution of body condition score after calving in dairy cows. Ann. Med. Vet., 143: 265-270.

Dubuc, J.; Duffield, TF.; Leslie, KE.; Walton, JS. and LeBlanc, SJ. (2012): Towards a better understanding of the respective effects of milk yield and body condition dynamics on reproduction in Holstein dairy cows. Animal, 6: $476-87$

Edmonson, AJ.; Lean, IJ.; Weaver, LD.; Farver, T. and Webster, G. (1989): A body condition scoring chart for Holstein dairy cows. J. Dairy Sci., 72: 68-78.

Ferguson, JD.; Galligan, DT. and Thomsen, N. (1994): Principal descriptors of body condition score in Holstein cows. J. Dairy Sci., 77: 2695-2703.

Fubini, SL. and Ducharme, NG. (2004): Farm Animal Surgery, 1st edn. Saunders, Elsevier. pp. 390-394.

Hegazy, MA.; Essawy, SA.; Teleb, HM.; El-Wishy, AA. and Youssef, AH. (1994): Effect of body condition score on reproductive performance of buffaloes. In: Proc IV World Buffalo Congress, São Paulo, Brazil, p 630-631.

Gautam, G. and Nakao, T. (2009): Prevalence of urovagina and its effects on reproductive performance in Holstein cows. Theriogenology, 71: 1451-1461.

Gautam, G.; Nakao, T.; Koike, K.; Long, ST.; Yusuf, M.; Ranasinghe, RM. and Hayashi, A. (2010): Spontaneous recovery or persistence of postpartum endometritis and risk factors for its persistence in Holstein cows. Theriogenology, 73: $168-79$. 
Gilbert, RO.; Wilson, DG.; Levine, SA. and Bosu, WT. (1989): Surgical management of urovagina and associated infertility in a cow. J. Am. Vet. Med. Assoc, 194: 931-9322.

Kasimanickam, R.; Duffield, TF.; Foster, RA.; Gartley, CJ.; Leslie, KE. and Walton, JS. (2004): Endometrial cytology and ultrasonography for the detection of subclinical endometritis in postpartum dairy cows. Theriogenology, 62: 9-23.

Kadarmideen, H.N. and Wegmann, S. (2003): Genetic parameters for body condition score and its relationship with type and production traits in Swiss Holsteins. J. Dairy Sci., 86: 3685-3693.

Lassen, J.; Hansen, M.; Sørensen, MK.; Aamand, GP.; Christensen, LG. and Madsen, P. (2003): Genetic analysis of body condition score in first-parity Danish Holstein cows. J. Dairy Sci., 86: 4123-4128.

LeBlanc, SJ. (2008): Postpartum uterine disease and dairy herd reproductive performance: a review. Vet. J., 176: 102-14.

Lubis, A. and Fletcher, IC. (1985): Body condition score in swamp buffalo cows. Research Report. p. 31, Indonesian Research Institute for Animal Production, Bogor.

Malik, MR.; Crao, K.; Taluja, JS. and Shrivastava, AM. (1990): Length and girth as an index to surface pelvimetry in buffalo. Indian J. Anim. Sci., 60: 1200-1202.

Malik, MR.; Taluja, JS. and Parmar, ML. (1992): Length and girth as an index to surface pelvimetry in cross-bred cow. Indian J. Vet. Anat, 4: 54-57.

McDougall, S.; Macaulay, $R$. and Compton, $C$. (2007): Association between endometritis diagnosis using a novel intravaginal device and reproductive performance in dairy cattle. Anim. Reprod Sci., 99: 9-23.
Nakao, T.; Moriyoshi, M. and Kawata, K. (1992): The effect of ovarian dysfunction and endometritis on subsequent reproductive performance in high and medium producing dairy cows. Theriogenology, 37: 341-349.

Parkinson, TJ. (2001): Infertility in cow. In: Noakes DE, Parkinson TJ, England GCW (eds), Arthur's Veterinary Reproduction and Obstetrics, $8^{\text {th }}$ ed.

Runciman, DJ.; Anderson, GA.; Malmo, J. and Davis, GM. (2008): Use of postpartum vaginoscopic (visual vaginal) examination of dairy cows for the diagnosis of endometritis and the association of endometritis with reduced reproductive performance. Aust. Vet. J., 86: 205-513.

Rao, KS.; Kumar, GD. and Kailash, MM. (2002): Influence of calving on body condition score (BCS). Indian J. Anim. Sci., 72: 882-886.

Roche, JR.; Dillon, PG.; Stockdale, CR.; Baumgard, LH. and Van Baale, MJ. (2004): Relationships among international body condition scoring systems. J. Dairy Sci., 87: 3076-3079.

Williams, EJ.; Fischer, DP.; Pfeiffer, DU.; England, GCW.; Noakes, DE. and Dobson, H. (2005): Clinical evaluation of postpartum vaginal mucus reflects bacterial infection and the immune response in cattle. Theriogenology, 63: 102-117.

Zobel, R.; Tkalčić, S.; Stoković, I.; Pipal, I.; Buić, V. (2012): Efficacy of ozone as a novel treatment option for urovagina in dairy cows. Reprod Domest Anim., 47: 293-298.

Zulu, VC.; Nakao, T.; Moriyoshi, M.; Nakada, K.; Sawamukai, Y.; Tanaka, Y. and Zhang, W. (2001): Relationship between body condition score and ultrasonographic measurement of subcutaneous fat in dairy cows. AsianAustralian J. Anim. Sci., 14: 816-820.

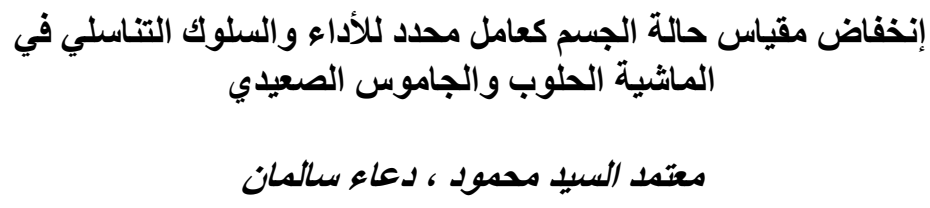

Email: motamed71111@yahoo.com

Assiut University Email: www.aun.edu.eg

\footnotetext{
الخلفية البحثية: مقياس حالة الجسم في الماثية الحلوب هو أداة هامة للرعاية في نظم الألبان الحديثة والذي يتغير بتغير موسم الحليب

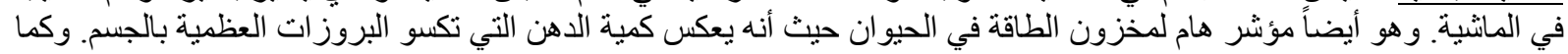

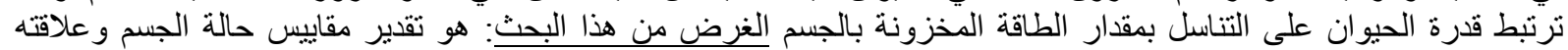

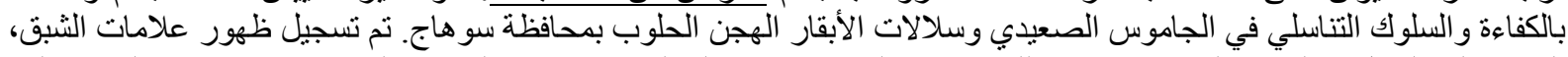

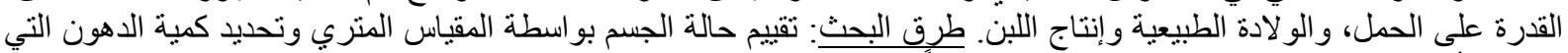

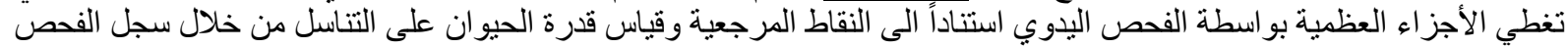

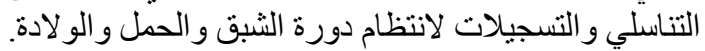

أهم النتائج: إضافة ذاوية الزيل الى تسجيل حالة الجسم لما له من إرتباط مباثر بالأداء الأنتاجي حيث أنه كلما انخفض مقياس الجسم

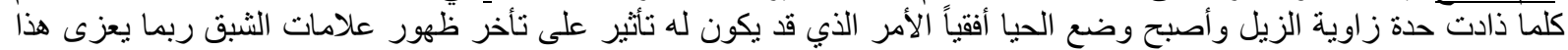

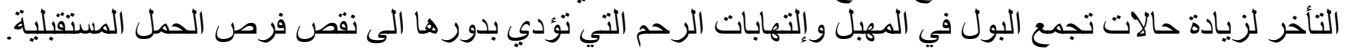

